\title{
A Charter for Nature Protection in Tropical Africa
}

\section{André AubrévilLE ${ }^{1}$ \\ Translation \\ by Ilona BOSSANYI}

${ }^{1}$ Inspector-General for Water and Forests in Overseas

France

${ }^{2}$ Bois et Forêts des Tropiques

Translation from the original article published in French in the issue $n^{\circ} 34$ of the journal Bois et Forêts des Tropiques, March-April 1954.

A conference on the conservation of fauna and flora was held in the Belgian Congo, at Bukavu (Costermansville) from 26 to 31 October 1953.

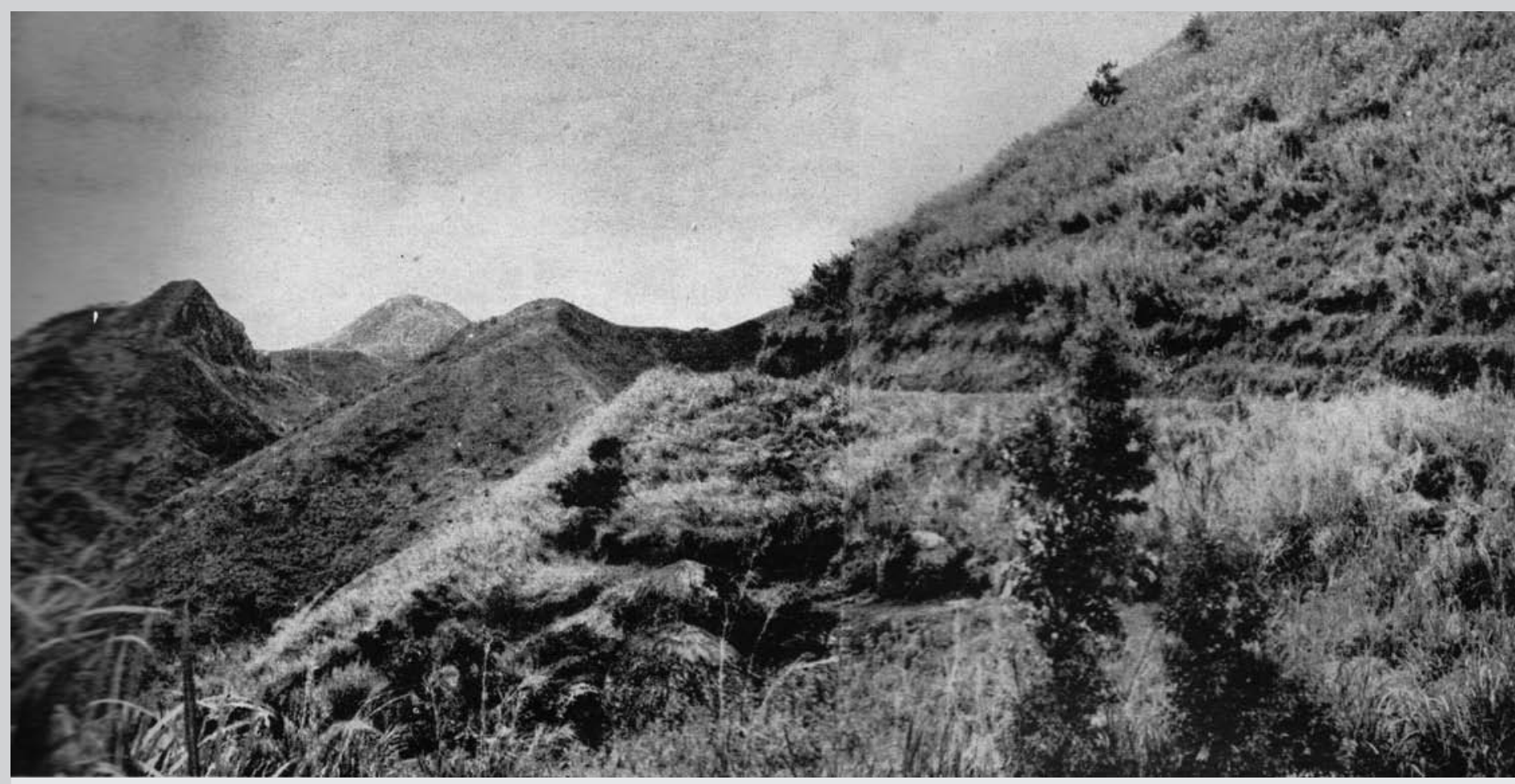

Photo 1.

The land of the Bukavu Conference (Belgian Congo): until such time as a forest protection policy takes effect, such is the melancholy aspect of mountainsides stripped of their trees and now covered in high Pennisetum savannah. On the road to Goma at Bukavu, on the western shores of Lake Kivu.

Photograph A. Aubréville, 1953. 


\section{RÉSUMÉ}

\section{UNE CHARTE DE LA PROTECTION DE LA NATURE EN AFRIQUE TROPICALE}

Lors de la Conférence sur la Conservation de la faune et de la flore à Bukavu (26-31 octobre 1953), une délégation française a présenté une recommandation, adoptée à l'unanimité, en faveur d'une politique générale de protection de la nature en Afrique. La Convention de Londres de 1933, réservée à la « conservation de la faune et de la flore à l'état naturel », apparaît en effet insuffisante. La conservation de quelques espèces animales ou végétales, et la constitution de parcs nationaux et de réserves naturelles ne constituent en effet qu'un point particulier d'une protection de la Nature qui doit s'étendre à la protection du milieu dans lequel vit l'humanité africaine. Il s'agit de protéger la couverture végétale spontanée, protectrice des eaux et des sols. Celle-ci recouvre les forêts mais aussi les "brousses " indéterminées. Une convention spécifique à l'Afrique se justifie parce que la nature africaine est différente et plus gravement menacée que d'autres. Elle l'est par le caractère extrême de son climat, mais aussi par les feux de brousse et l'agriculture sur brûlis, qui font vivre une population sous-alimentée. La savanisation, l'appauvrissement et l'érosion des sols, la désertification y progressent. Une politique de protection commune à tous les territoires africains est devenue indispensable pour assurer cette protection, comme elle l'est tout autant pour lutter contre les épidémies. L'Afrique est un tout qui ne connaît pas de frontières, mais rassemble des régions naturelles interagissant au plan climatique. Au-delà d'une Charte pour la protection de la nature en Afrique, il s'agit toutefois bien de la protection des populations africaines, lesquelles ne doivent cependant pas être soumises à un planisme scientifique qui ignorerait leurs pratiques coutumières.

Résumé adapté par la rédaction de la revue.

Mots-clés : conservation des eaux et des sols, conservation des forêts, conservation de la nature, Convention de Londres, couverture végétale, désertification, savanisation, Afrique.

\section{ABSTRACT}

\section{A CHARTER FOR NATURE PROTECTION IN TROPICAL AFRICA}

During the Bukavu Conference on flora and fauna conservation (26-31 October 1953), a French delegation submitted a recommendation, which was unanimously adopted, calling for an overall policy for nature protection in Africa. The 1933 London Convention, which only addressed the "conservation of fauna and flora in their natural state", no longer seems adequate: the conservation of a few animal or plant species and the creation of national parks and nature reserves only address particular areas of nature conservation, which need to be extended to protect the whole environment in which African people live. This includes spontaneous vegetation, which protects water and soils and forms not only forests but also indeterminate "bush". A specific convention for Africa is justified because nature in Africa is different and more seriously endangered than elsewhere. It is in danger because of the extreme climate, but also from bush fires and slash-and-burn agriculture that cannot sustain the undernourished population. Savannah encroachment, soil erosion and impoverishment and desertification are gaining ground. A common policy for all African territories has become essential to ensure their protection, and also to fight epidemics. Africa's nature forms a whole that has no boundaries, but natural regions that interact climatically. Over and above a Charter for nature protection in Africa, the issue is that of protecting Africa's populations, but without subjecting them to scientific planning that disregards their customary practices. Abstract adapted by the editorial team.

Keywords: soil and water conservation, forest conservation, nature conservation, London Convention, plant cover, desertification, savannah encroachment, Africa.

\section{UNA CARTA PARA LA PROTECCIÓN DE LA NATURALEZA EN ÁFRICA TROPICAL}

En la Conferencia sobre la Conservación de la Fauna y Flora de Bukavu (26-31 de octubre de 1953), una delegación francesa presentó una recomendación, adoptada por unanimidad, a favor de una política general de protección de la naturaleza en África. El Convenio de Londres de 1933 , reservado a la "conservación de la fauna y flora en su estado natural", se muestra insuficiente. En efecto, la conservación de ciertas especies animales o vegetales, así como la constitución de parques nacionales y reservas naturales, sólo supone un aspecto particular de una protección de la Naturaleza que debe extenderse al entorno en el que vive la humanidad africana. Se trata de proteger la cobertura vegetal espontánea, protectora de aguas y suelos. Dicha cobertura cubre los bosques, pero también los “matorrales" indeterminados. Un convenio específico para África se justifica porque la naturaleza africana es diferente y corre un mayor riesgo. Está amenazada por el carácter extremo de su clima, pero también por los fuegos de matorral y la agricultura de roza y quema que no permiten subsistir a una población subalimentada. La sabanización, el empobrecimiento y erosión de los suelos y la desertificación no dejan de aumentar. Se ha vuelto indispensable establecer una política de protección común a todos los territorios africanos para hacerla efectiva, al igual que se necesita una política común para luchar contra las epidemias. África es un todo que no conoce fronteras, pero agrupa regiones naturales que interactúan en el plano climático. Más allá de una carta para la protección de la naturaleza, se persigue la protección de toda la población africana, sin que ello derive en planificaciones científicas que ignoren sus prácticas ancestrales.

Resumen adaptado por la redacción de la revista.

Palabras clave: conservación de aguas y suelos, conservación de bosques, conservación de la naturaleza, Convenio de Londres, cobertura vegetal, desertificación, sabanización, África. 
Most of the governments with responsibilities in Africa were represented: Belgium, Belgian Congo, Egypt, France, Italy, Portugal, Southern Rhodesia, United Kingdom, Anglo Egyptian Sudan, Union of South Africa. Also attending the conference were representatives from many international organisations including UNESCO [United Nations Educational Scientific and Cultural Organisation], CTCA [Committee for Technical Cooperation in Sub Saharan Africa], IUPN [International Union for the Preservation of Nature] and CSA [Scientific Council for Africa], and Belgian scientific organisations including the INEAC [Institut National pour l'Étude Agronomique du Congo Belge], the IRS [Institut de Recherche Scientifique en Afrique Centrale], IPNBC, etc.

A great many recommendations were adopted, particularly on the protection of wild fauna and the regulation of hunting; I will not comment on these in this article, which is written for a forestry journal. However, in an aside from the initial agenda, I was able to present, on behalf of the French delegation, a recommendation of a fundamental nature on nature protection in Africa, which was adopted unanimously. The recommendation is couched in these terms:

"The Conference,

1. Having noted the indisputably effective results of the policy for protecting fauna and flora in Africa set out in the London Convention of 1933, and

2. Believing that the contracting governments should pursue or intensify the implementation of this policy;

3. Considering that the question of nature protection in Africa and the solutions thereto are of far wider import than those concerning fauna and flora as set out in the 1933 Convention;

4. Considering, in other words, that the vital question of safeguarding human habitat, as it arises in Africa, cannot be resolved purely by creating nature reserves and protecting certain rare or threatened species,

recommends

that the said Governments,

thereby taking a further step in the direction set out in Article 7, paragraphs 5, 6 and 7 of the 1933 Convention, independently of the detailed review of said 1933 Convention in accordance with the recommendations of this conference,

should consider the preparation of another Convention setting out the essentials of an overall policy for nature protection in Africa, based on the wishes expressed by the technical conferences as regards protection of the soil, plant cover, water resources, etc., with a view to guaranteeing a conservation of the spontaneous plant cover, soils, water and natural resources, primarily in the interests of Africa's populations."

At this point I must go back in time, to the 8th November 1933 when the colonial powers in Africa signed an agreement in London to guarantee wildlife protection by applying certain measures. It is well known that certain plant and especially animal species are under threat of extinction. The contracting governments undertook to take a number of measures, especially involving the creation of nature reserves, the total or partial protection of certain species and the regulation of trophy hunting. However, over and above these measures specifically addressing the conservation of endangered species, a number of commitments were made to forest conservation: maintaining adequate planting rates, protection of the best timber species, regulation and control of fires along forest edges and close collaboration between forestry services.

These provisions are set out in very general terms. They have not attracted a great deal of attention in practice, although they usually form the basis of the numerous forest policies applied in many African countries. They do not stand out clearly in the 1933 London Convention. As the main goal is to create nature reserves and protect some species, the agreement itself is entitled "Convention on the conservation of flora and fauna in their natural state". The idea of conservation is now broader in scope since what it concerns is now referred to as the protection of nature, in which the conservation of certain animal or plant species and the creation national parks and strict nature reserves are only particular cases.

Protecting nature as a whole means protecting the environment in which African people live, in other words, the soils they cultivate, the water that is essential to their lives, whether in the form of rain falling from the sky or water flowing in rivers and on the ground, and, finally, what I have referred to in very general terms as spontaneous plant cover of the soil, which offers the best protection for soils and water. This spontaneous plant cover includes all forests and indeterminate kinds of "bush", all plant formations that are not usually referred to as forests but which, even in deserts, have a role in protecting soils which is directly useful to man.

In recent years, the questions that arise on nature protection in Africa have been the subject of a great many studies and proceedings: the conference on African soils held in Goma, in the Belgian Congo, in October 1949, addressed the whole range of issues concerning rational uses of the soil, the Abidjan conference in December 1952 addressed African forest issues and the international technical conference on nature protection, held at Lake Success in August 1949 under the aegis of UNESCO, addressed the same issues from the global angle. In all the exchanges of views and discussions that took place during these international meetings, the same idea emerges of the possibility, the usefulness and even the necessity of defining, and then applying, a specific policy for nature protection in Africa, because nature in Africa differs from elsewhere and because it is in greater peril than elsewhere.

Up to now, no similar initiative seems to exist for other parts of the world. Although Europe is very densely populated and its natural environment has been exploited for centuries, the problems that arise there do not demand concerted action or exceptional measures from Europe's governments. Each country took measures long ago to create and conserve forest domains, to protect and restore soils in mountain areas, etc. In the United States, although soil erosion is known to have become extremely serious, we also know of the protective measures already applied by the departments responsible for soil conservation.

Tropical Africa is in great danger, but we are only beginning to realise the fact. This is a consequence of its extreme 
become a true Charter for Nature Protection in Africa. There would be real psychological, political and practical value in such an international agreement. Psychological because a solemn undertaking that is binding on populations, their governments and their assemblies would signify official recognition of the importance of nature protection. We know that this importance, though often proclaimed by specialists and scientists, is not always accepted or understood by populations and government administrations, whose concerns are mainly for immediate problems and the present generation. Every African wants what is best for his own children, but this concern does not usually extend to the common legacy of all future generations. Africa's potential habitability and productiveness, which is shrinking a little each day due to destructive or negligent practices, needs to be kept intact or, better still, improved. This is the idea that must be gradually instilled in everyone's minds. A Charter would be a powerfully persuasive tool to achieve this.

The political value of such a Charter would be far from negligible. Too many nations today envy the destiny of the European countries that History has brought into Africa. There are many who deny the civilising influence that has borne fruit in such a short time, with limited means, in countries where difficulties abound on every front. Their intentions may be obvious, but they are not pure. It is said or suggested that these tutelary nations are not making every effort they should to lift these African countries out of their backward state, or that their efforts are purely selfish in nature. What better proof of altruism could there be than to undertake, through a Charter, to take every possible measure to ensure that Africa does not succumb to the physical dangers that threaten it, and to attach the greatest possible importance to the problems of nature protection in Africa?

But such a Charter is more than a founding political act or a simple declaration of good intent. I myself can perceive its realistic and practical nature. Of course, the commitment made by governments is a moral one, and can only bind them as far as their resources and local circumstances permit. It is the responsibility of the relevant authorities to apply it with due consideration for all contingencies. Over-estimating the latter could in fact cancel out the effects of the Convention. I am nevertheless convinced that in many countries, if not all, there are key figures who will strive to put the undertakings made by governments to the best possible use. In the territories of the French union, international agreements signed by the Government and amended by Parliament have the force of law. This is a crucial point, because the executive departments are under obligation to apply the law by every means they possess. There will always be men of good faith, within these departments or elsewhere, who will use the law for the good of Africa and, if necessary, against the hesitant, the sceptical and those who mask their selfishness in a pretence of realism.
Objections will nevertheless surely arise to a Charter that would appear to give priority to the protection of nature over the protection of man. This priority is only apparent, of course, since the pre-eminent need to protect Africa's populations is fundamental to all the policies of Africa's tutelary nations. Changes in the legislation and measures taken by public authorities clearly show that concerns for public health and improved living conditions are always and everywhere the priority. Today, social questions are always treated on the same level as economic questions, since the two are in fact closely linked. The question of nature protection has perhaps often been presented, and especially understood, as a matter of purely scientific concern. Certainly, scientific concerns were the driving force behind the 1933 London Convention, naturally enough, since scientists and naturalists were the first to perceive the dangers looming over Africa's wildlife. It is to their credit that they sounded the alarm. Today, however, the scientific aspect of the nature protection question, although it continues to be considered equally important, comes next in priority to safeguarding Africa's habitability and resources in the interests of its inhabitants. In seeking to protect nature in Africa, we are seeking first of all to protect Africa's people. It is not possible to separate them from their environment, or to improve their living standards within a natural environment that is becoming less and less able to support them. Plants that have been selected for their high yields can be cultivated on sterile soils. A human civilisation can only develop fertile soils with abundant water. The greatest civilisations will perish if their soils become sterile and their water disappears.

An international agreement could also raise a different concern, that of being applied rigidly without consideration for the conditions that determine the actual situation of things and people. Some will be suspicious of the possibilities for taking rationalisation and the rigours of logic to extremes, which, even with the best will in the world, can lead to inhuman conceptions and approaches. We are too familiar with the realities of Africa and its limited possibilities not to accept the inevitable need for compromise between what should be done and what can be done. It is out of the question to subject these populations to purely scientific planning that gives no consideration to their day-to-day needs and customary practices and brutally bans them even if specialists recognise that they are harmful to nature conservation. We must safeguard day-to-day living before looking to the survival and welfare of our distant descendants. An international convention can therefore only set out very general commitments to inspire farsighted policy-making. As regards measures to apply the convention, we must put our trust in the political wisdom of the administrative and elected authorities, but they must never forget or lose sight of the Charter that will set out their duty and responsibility for the future. 